\title{
THE ROLE AND IMPORTANCE OF ECONOMIC COOPERATION OF THE VISEGRAD GROUP COUNTRIES IN THE EUROPEAN UNION
}

\author{
Krzysztof JASIECKI, PhD \\ Centre for Europe, University of Warsaw, Poland \\ k.jasiecki@uw.edu.pl
}

\begin{abstract}
The purpose of the article is to characterize the genesis, role, significance, conditions, and effects of economic cooperation of the Visegrad Group states in the European Union, with particular emphasis on their development after 2015. It presents the distinguishing features and specificity of the Group before the accession to NATO and to the EU in the context of the then situation of Central Europe and other European post-communist countries, as well as characterizes the most important aspects of the economic potential of the V4 states against the background of the EU and of some selected Member States. The strengths and weaknesses of economic cooperation in the region are discussed, as well as structural restrictions on the role of the Visegrad countries in the European Union and the controversy surrounding their cooperation. The last part contains conclusions referring the activity of the Visegrad Group to the main axes of post-crisis political and economic divisions in the EU, with particular emphasis on their economic dimensions.
\end{abstract}

Keywords: economies of the Visegrad Group countries in the EU, structural limitations of the role of the Visegrad Group countries in the EU, controversy around cooperation of the V4 countries.

\section{Introductory remarks}

The activities of the Visegrad Group (The V4) states in the EU since 2015 are being considered in a new way. They have a more controversial nature, which, among other things, reflects the broader trends of political and economic change since the 2007-2009 global financial crisis. The Group's policy has been part of the divisions in the EU, which currently run mainly between: 1) the countries with trade and budget deficit and those with trade and budget surplus; 2) the countries of the developed northern "core" and southern and eastern low-innovative "peripheries", 3) the euro area and the "second-speed" countries (outside the euro area); 4) the 
countries accepting and those opposing to the admission of migrants from North Africa and the Middle East, and 5) the countries complying with and those non-complying with the EU rule of law (Zielonka, 2018; Góralczyk, 2018; Bohle and Greskovits, 2012).

The Group's activity in the EU acts as a catalyst for autonomous and centrifugal tendencies also in other European post-communist countries and inspires new projects, including The Three Seas Initiative inaugurated in August 2016 in Dubrovnik, and discussed as a new regional cooperation model (Zbińkowski 2019; Muresan, Georgescu, 2017). In the post-crisis political and economic circumstances, such actions in some EU countries (not only the "old" Union) are interpreted as a manifestation of the revival of a $\mathrm{n}$ into "the East" and "the West". "In the opinion of critics, the Visegrad Group's previously positive image has been changed to non-empatic, and non-solidary" (Orzelska-Stączek 2019, p. 127). The purpose of the article is to characterize the role, significance, conditions, and effects of cooperation between V4 countries in a changing EU.

\section{The Visegrad Group before the accession to NATO and to the EU}

The Visegrad Group is a regional faction formed by four post-socialist countries of Central Europe. The name comes from the Hungarian town of Visegrad, in which in 1991 the declaration of cooperation in the pursuit of integration with the European Communities was signed by Lech Walesa, the President of Poland, Vaclav Havel, the President of Czechoslovakia and Józef Antall, the Prime Minister of Hungary. This group, known as the Visegrad Triangle, after the collapse of Czechoslovakia in 1993 transformed into the Visegrad Group formed by Poland, Hungary, the Czech Republic, and Slovakia (hence the term The Visegrad Four, the V4). The Visegrad states had common goals: implementing democratic and market reforms as well as joining NATO and the EU as soon as possible after the collapse of the Mutual Economic Assistance Council (Comecon) and of the Warsaw Pact in 1991. It was also about obtaining Western financial aid and foreign investments necessary to carry out reforms after the collapse of the command and distribution economy and trade relations in the Comecon.

The V4 countries (plus Romania) have the largest economies among the post-socialist countries within the EU, and geographically are strategically located in Europe. They are often treated as anticipating broader trends of political and economic changes occurring also in the other countries of Central and Eastern Europe (CEE). Against this background, cooperation within the Visegrad Group had from the beginning features that essentially determined its further 
development: 1) weakness of formalized political structures; 2) clear Atlantic orientation in terms of security; 3) a market-oriented economic attitude stronger than in the European mainstream; and 4) support for further enlargement of the EU to include other post-communist countries. "From the beginning, the Visegrad Group was described as a "cooperation forum", an "informal grouping", a "cooperation structure" [...], a "political lobby group", or simply the "V4" (OrzelskaStączek, 2019, p. 119).

The V4 activity was particularly significant in the early 1990s. The most important common denominator of the policy of the countries of the region (with the temporary exclusion of Slovakia) was the direction of political and economic changes based on liberal-democratic consensus and the desire for rapid rapprochement with the West. However, the development of the Group was limited by scepticism towards the creation of strong V4 institutions, which distinguished Czech politicians in particular, perceiving their country as the best in the region prepared for accession to NATO and to the EU (fearing that strengthening the institutions of the Visegrad Group may put a strain on this process). The effectiveness of the V4 was also limited by the rule of Vladimir Meciar in Slovakia between 1993 and 1998, considered by the Western states to be authoritarian and undemocratic, which halted the country's negotiations with NATO and with the EU (Malova, 2017; Sikulova and Frank, 2013, pp. 23-27). On the other hand, the strong Atlantic orientation resulted from the historical experience of the countries of the region fearing that the breakup of the Union of Soviet Socialist Republics (USSR) and the weakening of Russia's imperial ambitions may be a temporary phenomenon. Exiting the grey security zone between the East and the West required a new root in a stable alliance, guaranteed by NATO.

The decidedly neo-liberal orientation of the reformers in the V4 resulted from the will to quickly transform the economies towards the market and from their openness onto international connections. In accordance with the recommendations of the IMF and of the World Bank, such actions increased the chances of significant economic growth based on the principles of developed countries and foreign capital. It was believed that due to the development gap between the V4 and Western Europe, more radical actions were necessary than those in the "old" Union, where the market economy had been built for generations. Leszek Balcerowicz in Poland and Vaclav Klaus in the Czech Republic became symbols of a novel approach to reforms, recognized as a model for the European post-communist countries. The V4 Group created a positive example of regional development, stability, and good relations with other countries (Aslund, 2008). It played a more 
important role in that it operated in an area known in the past for frequent wars, political, social and national conflicts as well as for changes in national and territorial affiliations.

The creation of the V4 was an argument in the relations of its members with the EU, especially against the background of dramatic events in countries arising after the collapse of the Socialist Federal Republic of Yugoslavia (SFRY) and some countries of the former USSR (Góralczyk, 1999). A strong impulse strengthening cooperation was the invitation to the "Partnership for Peace" program and then to join NATO. The effect was, among other things, supporting Bratislava in catching up with integration after the fall of Meciar's government and in the efforts to join the EU. The new status of the countries of the region strengthened the prestige and attractiveness of the Visegrad cooperation ${ }^{1}$.

\section{The migration crisis and the political revival of the $\mathrm{V4}$}

The accession of the Visegrad states to NATO and to the EU meant that the most important premises for developing regional cooperation disappeared. Each state began to pursue its own interests, which weakened the political possibilities of the region. After joining the major EuroAtlantic organizations, the V4 states failed to develop a new, comprehensive vision of cooperation in policies in the following areas: foreign, defence, security, economic, euro, energy, etc. The frequently asked question at the time was: "Is there a future for the V4?" (McDonagh, 2014). Old animosities were activated, and different political concepts came to the fore. Poland, the largest country of the four, showed ambitions to co-decide on the directions of the EU and NATO development (e.g. through cooperating with Germany and France in the Weimar Triangle). However, the other Group members did not support these leadership aspirations, and the V4 as a whole did not have a common cooperation strategy ${ }^{2}$.

At the same time, the consequences of the global financial crisis that spread to the euro area meant that the EU ceased to be perceived by CEE only as a modernization opportunity. It became a source of political, economic and/or migration problems. The crisis also diversified

\footnotetext{
${ }^{1}$ The expansion of the Group was considered, and Lithuania, Slovenia, Romania, Bulgaria and Croatia were mentioned among potential members. However, the V4 leaders decided that the Group would not be expanded. Researchers distinguishes three stages in the functioning of the V4: the accession stage (1992-2004), the integration stage (2005-20014) and since 2015, the Eurosceptic stage (Orzelska-Stączek, 2019, p. 126).

${ }^{2}$ The head of the Slovak Ministry of Foreign Affairs in the discussion on the role of Poland in the V4 expressed the view that "having leaders would be dangerous, because it would be difficult to fight for national interests" (Kubisz, 2008).
} 
reactions to the new problems and challenges: Hungary and Poland started to strongly emphasize the importance of the nation-state and partly reverse the directions of political changes of the 1990s; Slovakia joined the euro area in 2009 and continues to strengthen its integration with the "core" EU countries; all the V4 countries are redefining the goals and forms of cooperation resulting from the changes within the European Union and in its external environment. However, the most important catalyst for political change turned out to be the migration crisis of 2015 . The Willkommenskultur policy of Chancellor Angela Merkel and the EC's proposals on compulsory quotas for refugees, not consulted with the EU partners, aroused opposition of the CEE countries. They launched consolidation reactions and defined a new common denominator for the political cooperation of the V4 states. The position of the Hungarian government was particularly important in this respect, which after the passage through its territory of 200,000 migrants heading for Germany and Sweden, considered them a threat to the social order and Hungarian national identity. The other V4 countries joined this position, including Poland after the change of government in 2015.

This had various consequences. In domestic politics, it strengthened support for right-wing, nationalist, and anti-immigrant groups that referred to slogans for defending traditional values and national identity. This brought about a new division in the V4 relations with the EU, especially in relations with Southern Europe, which has been struggling with the refugee issue to the greatest extent (Chojan 2019). In Central Europe, the migration crisis became a pretext to manifest greater assertiveness in relations with the EU, which is an indication of political changes related to the seizure of power by anti-liberal and Eurosceptic parties. In Hungary and Poland (to a lesser extent in the Czech Republic and in Slovakia), the V4 Group is treated as a tool for populist, authoritarian and neoconservative policy aimed at limiting the influence of the liberal West and its institutions, including the EU ${ }^{3}$. The Group's strength is to build political coalitions that could represent the interests of other CEE countries as well (Jasiecki, 2019).

\section{The economic and demographic potential of the Visegrad countries in the EU}

The importance in the EU of the V4 countries considered together is illustrated by selected economic and demographic indicators. According to Eurostat, the region's countries accounted for

\footnotetext{
${ }^{3}$ Like the Three Seas Initiative, V4 activities are currently being interpreted in various ways: 1) complementing European integration, strengthening the region's cooperation in defence against Russian neo-imperialism; 2) counteracting the dictates of Berlin, Paris and Brussels; 3) creating an alternative to the possible deepening of the EU crisis (Świder, 2018, p. 25).
} 
$5.6 \%$ of total EU-28 GDP in 2017 (12.6\% of the EU population). In comparison, it was $21.3 \%$ of EU GDP in Germany, $15.2 \%$ in the United Kingdom, $14.9 \%$ in France, $11.2 \%$ in Italy, and 7.6\% in Spain. The data also indicate the asymmetry of potentials between the V4 countries and the EU and Germany, whose share in the EU population is about $16 \%$, and whose GDP is four times as high as that of the V4 states $^{4}$. However, although the economies of the Visegrad countries - except for Poland - are small, they are developing more dynamically than the euro area countries and remain attractive for foreign investors. The euro crisis and changes in the EU, especially Brexit, further increase the importance of the V4 countries in the EU (see Table 1). The role of the V4 Group as an industrial base and factor of competitiveness of the German economy is particularly growing. "Since 1989, Germany has become the most important trade and investment partner for the V4 countries, which had a significant impact on the evolution of the Central European economic model and helped in the process of modernizing the region." At the same time, "the countries of the Visegrad Group have become Germany's most important global partners in both export and import" (Popławski, 2016, p. 5).

Table 1. Area, population and GDP of the V4 against Germany and the EU (2017)

\begin{tabular}{|c|c|c|c|c|c|}
\hline & Czech Republic & Hungary & Slovakia & Poland & Germany \\
\hline Area $\left(\mathrm{km}^{2}\right)$ & 78868 & 93011 & 49035 & 312697 & 357380 \\
\hline Population (million) & 10.6 & 9.8 & 5.4 & 38 & 82.5 \\
\hline $\begin{array}{l}\text { Population as \% of the } \\
\text { whole of the UE }\end{array}$ & 2.1 & 1.9 & 1.1 & 7.5 & 16.1 \\
\hline $\begin{array}{l}\text { GDP in Euro (million) } \\
\text { current prices }\end{array}$ & 191.7 & 124.1 & 84.9 & 467.3 & 3277.3 \\
\hline GDP share UE 28 & 1.2 & 0.8 & 0.6 & 3.0 & 21.3 \\
\hline $\begin{array}{l}\text { GDP per capita in PPS } \\
\text { Index (UE } 28=100 \%)\end{array}$ & 89 & 68 & 76 & 70 & 124 \\
\hline
\end{tabular}

Source: Eurostat 2019

Especially since the 2008-2009 euro crisis affected the V4 countries to a much lesser extent than it did the Baltic Republics, reducing GDP in Hungary by $6.7 \%$, in Slovakia by $5.5 \%$ and in

\footnotetext{
${ }^{4}$ Even greater asymmetry between the level of economic development and the number of inhabitants characterizes Romania. According to Eurostat data from 2017, Romania generates $1.2 \%$ of EU GDP, although it is inhabited by $3.8 \%$ of the EU population (19.6 million citizens).
} 
the Czech Republic by $4.3 \%$ (for comparison: this decrease in Latvia was 17\%, in Lithuania 15.8\%, and in Estonia 12.3\%) (Gorzelak and Goh, 2010). Poland was the only EU country that achieved a 1.7\% increase in GDP during that period. According to Eurostat, at the end of 2017, the share of the Polish economy in the EU GDP is greater than that of Belgium (2.9\%) and approached that of Sweden $(3.1 \%)$.

\section{The strengths and weaknesses of economic cooperation in the V4}

The Visegrad Group was one of the important centres of activity focused on rapprochement with the economic structures of Western Europe, as exemplified by the creation of the Central European Free Trade Agreement (CEFTA) of 1992. This aspect of cooperation was also developed after the accession to the EU of the countries of the region. For instance, during the Polish leadership in the V4 in 2016-2017, development of cooperation was declared in the fields such as EU transport and energy policy, the Digital Single Market and optimization and sealing of tax systems. Joint arrangements were reached on the EU cohesion policy, actions for the single market, internal security and defence, climate, and environmental protection, as well as on the migration policy. Regular and ad hoc consultations with high-level politicians, expert meetings, preparation of joint documents on key issues (declarations, letters of intent, meetings of ambassadors, etc.) were indicated as the main mechanisms and instruments ${ }^{5}$. However, the Visegrad countries did not create positive economic synergies (internal and/or external) and they did not develop any significant infrastructure projects. Due to capital and technology deficits, they compete against each other in order to secure foreign investment, especially in the automotive industry (Kużelewska and Bartnicki, 2017, p. 104).

There are several main reasons for their poor economic cooperation. Initially, they included the following: low level of economic development compared to EEC/EU countries, early stage of creating modern market institutions, high costs of systemic changes, deficits in investment capital as well as weakness of native middle classes and of business elites. First and foremost, the V4 states needed capital and technologies from more developed countries, as well as markets and distribution networks that generated demand for their products. There was an expansion of exports

\footnotetext{
${ }^{5}$ Work on V4 cooperation is also underway with representatives of other countries, in particular Bulgaria, Croatia, Romania and Slovenia and partners from outside the EU, e.g. South Korea. Meetings are also held with representatives of the Benelux Union and the Nordic Council.
} 
to western countries and an increase in the quality of commercial and production offer. The prospect of accession to the Union made the economies of the Group more dynamic; however, due to their low complementarity and coherence, asymmetrical economic relations were created especially with Germany, which opened up more opportunities for cooperation than integration under the V4. One of the effects of such relationships is the low level of synergy and economic integration in the V4, as illustrated by export and import exchange which shows that Germany is the main trade partner of the V4 Group, while export and import links with Germany keep growing, least in the case of Slovakia (Tables 2-3).

Table 2. The main directions of exports of the V4 countries (\%)

\begin{tabular}{|c|c|c|c|c|c|c|c|}
\hline \multicolumn{2}{|c|}{2016} & \multicolumn{2}{|l|}{2012} & \multicolumn{2}{|l|}{2016} & \multicolumn{2}{|l|}{2012} \\
\hline \multicolumn{4}{|c|}{ Czech Republic } & \multicolumn{4}{|l|}{ Hungary } \\
\hline Germany & 32.4 & Germany & 31.4 & Germany & 27.9 & Germany & 25.1 \\
\hline Slovakia & 8.3 & Slovakia & 9.0 & Romania & 5.2 & Romania & 6.0 \\
\hline Poland & 5.8 & Poland & 6.1 & Slovakia & 5.0 & Slovakia & 6.0 \\
\hline U.K. & 5.2 & France & 5.1 & Austria & 4.9 & Austria & 5.8 \\
\hline UE-28 & 83.7 & UE-27* & 81.0 & UE-28 & 81.4 & UE-27 & 56.7 \\
\hline \multicolumn{4}{|l|}{ Poland } & \multicolumn{4}{|l|}{ Slovakia } \\
\hline Germany & 27.2 & Germany & 25.2 & Germany & 21.9 & Germany & 21.4 \\
\hline U.K. & 6.6 & U.K. & 6.8 & Czech Rep. & 11.9 & Czech Rep. & 14.1 \\
\hline Czech Rep. & 6.5 & Czech Rep. & 6.3 & Poland & 7.7 & Poland & 8.4 \\
\hline France & 5.4 & France & 5.9 & France & 6.2 & Hungary & 7.3 \\
\hline UE-28 & 79.6 & UE-27 & 76.0 & UE-28 & 85.5 & UE-27 & 83.8 \\
\hline
\end{tabular}

* In 2012, the EU did not include Croatia, which obtained its membership in 2013.

Source: The Economist 2019.

The role of such ties is strengthened by the fact that they have higher trade exchange with Germany per capita than France or the United Kingdom (with a significant increase after 2009) (Popławski, 2016, p. 18) ${ }^{6}$. The relations of the V4 countries with the EU market are equally stable, but in different proportions, and amount to exports from nearly $80 \%$ (Poland) to over $85 \%$ (Slovakia). An analogous situation applies to imports, in which the share of EU countries also dominates, although to a slightly smaller extent. The large dependence of the region's development on EU markets means that they are above average susceptible to changes in the economic situation

\footnotetext{
${ }^{6}$ Cooperation with the German economy is favoured by a large percentage of industry in the GDP of the V4 economies, which is among the highest in the EU. According to the World Bank, it was 32.2\% in the Czech Republic in 2018; 30.1\% in Slovakia, 28.6\% in Poland, $25.4 \%$ in Hungary and $27.4 \%$ in Germany.
} 
in the EU. The cooperation of the Visegrad countries is mainly of a political nature. However, the weak formalization of the Group and the lack of real coordination mechanisms (e.g. similar to those of the Benelux Union or to the Nordic Council), make it unable to generate its own political identity recognizable in the international environment.

Table 3. The main directions of imports of the V4 countries

\begin{tabular}{|c|c|c|c|c|c|c|c|}
\hline 2016 & & 2012 & & 2016 & & 2012 & \\
\hline The Czech F & blic & & & Hungary & & & \\
\hline Germany & 30.6 & Germany & 29,3 & Germany & 27.4 & Germany & 24.8 \\
\hline Poland & 9.7 & Poland & 7.7 & Austria & 6.6 & Russia & 8.8 \\
\hline China & 7,4 & Slovakia & 7.4 & China & 6.4 & China & 7.4 \\
\hline Slovakia & 6.3 & China & 6.3 & Poland & 5.6 & Austria & 7.2 \\
\hline UE-28 & 79.2 & UE-27 & 75.3 & UE-28 & 77.7 & UE-27 & 63.27 \\
\hline Poland & & & & Slovakia & & & \\
\hline Germany & 28.1 & Germany & 26.2 & Germany & 20.7 & Germany & 17.8 \\
\hline China & 7.8 & Russia & 11.5 & Czech Rep & 17.4 & Czech Rep & 17.1 \\
\hline Netherlands & 5.9 & Netherlands & 5.7 & Austria & 10.0 & Russia & 9.7 \\
\hline Russia & 5.7 & Italy & 5.1 & Poland & 6.7 & Hungary & 7.6 \\
\hline UE-28 & 72.1 & UE-27 & 67.7 & UE-28 & 80.2 & UE-27 & 73.6 \\
\hline
\end{tabular}

Source: same as above.

The current status of the V4 remains ambivalent and highly problematic due to the different objectives of its members, their divergent interests, ambiguity of the development line, the lack of a legislative dimension at the sub-regional level, as well as the lack of mechanisms for formal arrangements and consultations (e.g. in the form of a joint parliament with a limited legislative delegation). From historical point of view, "the Visegrad countries have not had positive experienced with regional cooperation; they are also not linked by strong common regional identity" (Orzelska-Skrzypek, 2019, p. 129, see also Roszkowski, 2015; Judt, 2005; Rothschild 1998).

\section{The structural limitations on the role of the Visegrad Group states in the EU}

The debt and economic crisis in the euro area undermined the concepts of rapid development convergence that underpin the EU. Its course also revealed the diversity of directions 
of changes in the European Union, which are manifested in the processes of political and economic divergence and the discussion of a "multi-speed" Europe. What is consolidated, among other things, is the distinction between highly developed "core" countries of the euro area, cantered around Germany, France, Benelux and Austria, and two groups of "peripheral countries" - in Southern Europe and Central and Eastern Europe (Myant, 2018; Jasiecki, 2013; Bohle and Greskovits, 2012). One of the main problems of post-communist system changes is the role of their structural dependencies in relations with the more developed countries of the "core" of the euro area. The common denominator of discussions on such relations is the thesis that the V4 countries joined the EU on principles that give advantage to the interests of Western corporations. The unprecedented rate of increasing the share of foreign investors in the region resulted in Western transnational corporations (TNCs) dominating the most important sectors in the system financial intermediation, telecommunications, export industries and retail.

The transition based on foreign capital in the second half of the 1990s was reflected in the definitions of the V4 states as variants of the new "transnational capitalism" (Bohle and Greskovits, 2012), "dependent market economy" (Nölke and Vliegenhart, 2009; Pula, 20018)7. Due to their position in the international division of labor, these countries are considered as FDIbased second rank market economies. Modelled on those of the EU, economic institutions of these countries relatively quickly integrated with international markets. Foreign investors dominate, and the development is based on exports with a growing share of highly processed goods, produced mainly by local branches of TNCs (Myant and Drahokoupil, 2011). A system was created that is a combination of export-oriented economic development, financially dependent and determined by the weakness of domestic capital accumulation compensated by foreign investment and EU funds. In this approach, the progressing "Europeanization" may, however, mean further "peripheralization" in the form of dependence on EU-15 import markets (especially Germany) and foreign credit and technologies ${ }^{8}$. Partial confirmation of the structural weaknesses of cooperation among the V4 economies is provided by data on ownership in the banking sector and in the group

\footnotetext{
${ }^{7}$ In application to Romania, discussions on various strategies for modernization and economic development from the perspective of political economy, taking into account the modern variant of "dependent neoliberalism" is characterized, among others, by Cornel Ban (Petrovici 2015).

${ }^{8}$ It is metaphorically illustrated by the essence of a Czech joke from the 1990s indicating two threats: 1) Germany will make huge investment and buy out the local economy and 2) Germany will not make any investment and the economy will stagnate (Judt, 1996, p. 151).
} 
of the largest 500 List companies, mostly controlled by foreign capital (see Tables 4-5). A characteristic feature of the economies of the region has become the dualism of the development of more productive and profitable companies with the participation of foreign investors and less effective domestic enterprises, as well as geographical and sectoral concentration of foreign direct investment (FDI).

Table 4. The share of various types of banks in the V4 market (2014)

\begin{tabular}{|l|l|l|}
\hline \multicolumn{2}{|l|}{ Banks controlled by capital (in\%) } \\
\hline country & Foreign & state-owned \\
\hline Czech Republic & 83 & 2.6 \\
\hline Hungary & 88 & 5.8 \\
\hline Poland & 62 & 21.0 \\
\hline Slovakia & 99 & 0.8 \\
\hline
\end{tabular}

Source: Deloitte, CE Top 500 CE TOP 500, “Rzeczpospolita”, 3.09.2014.

The capabilities of domestic companies necessary for long-term growth and competitiveness do not increase significantly. At the same time, the technological activity of branches of foreign corporations is often implemented without significant links with national innovation systems. These trends are deepened by regional, economic, and social diversity increased by the inflow of foreign capital and weakness of the representation of CEE's economic interests on the states level and the EU forum (Jasiecki 2019).

Table 5. The share of various types of ownership in the structure of the 500 largest enterprises in the V4 economies (2014) 


\begin{tabular}{|l|l|l|l|}
\hline country & Foreign & private domestic & state-owned \\
\hline Czech Rep. & 65.8 & 16.5 & 17.0 \\
\hline Hungary & 87.3 & 1.6 & 11.1 \\
\hline Poland & 56.8 & 19.0 & 23.5 \\
\hline Slovakia & 75.0 & 0.0 & 25.0 \\
\hline
\end{tabular}

Source: same as above.

In the sphere of consequences, they resemble in a new way the problems known from the theory of dependence and the theory of the world system that characterized island development and semi-peripheral countries. The manifestation of similar phenomena is the emergence of a new "metropolitan class," the elite of wealth and middle classes concentrated in the capitals - Budapest, Prague, Bratislava and in Warsaw and several major agglomerations in Poland (Pula, 2018, pp. 194-195; Jasiecki 2013). The crisis in the EU revealed also many other negative aspects of the V4 development based on foreign investment ${ }^{9}$, including a radical reduction in the lending activity of banks controlled by transnational capital, exchange rate risks passed on to enterprises and households (e.g. loans denominated in the Swiss francs), as well as a sharp decline in the export of companies with foreign capital. Accumulation of such phenomena and trends also contributed to the increase in the budget deficits in the region and the entry of some countries, like Hungary and Poland, into the procedures of excessive debt in the EU. A discussion about the costs of its service, including tax optimization and the inward/outward balance ${ }^{10}$ became part of the reaction of the countries of the region to the development based on foreign capital.

Repatriated profits abroad by foreign owners included in GDP were also considered a problem of the V4 countries; since 2010 their share is the largest in the Czech Republic - hovering at around 5\%, slightly smaller in Slovakia and Hungary, and the smallest (about 2\% per year) in Poland (Septimiu, 2019). Such estimates lead to the conclusion that the development in the Visegrad countries is in fact significantly smaller than shown by the official statistics. This is also a reason for explaining the discrepancy between GDP growth rates in these countries and a much slower improvement in the standard of living of the inhabitants. Dynamic economic changes in

\footnotetext{
${ }^{9}$ The financial weakness of the CEE countries is demonstrated by the share of banks in the region reaching a total of $1.5 \%$ in the structure of the EU banking sector's assets (Orłowski et al., 2018, p. 52).

${ }^{10}$ International investments are difficult to monitor and classify due to their often non-transparent origin. It is estimated that about $1 / 3$ of global financial flows are multiple transactions carried out by third countries, which leads to tax revenue losses, welfare losses, as well as distorted competition in the host country. TNCs, which benefit from tax preferences in some countries, make such transfers; in Europe, this applies to Cyprus, Luxembourg, the Netherlands and the UK (Aykut et al., 2017).
} 
recent years have created new structural barriers common (to varying degrees) for the V4 countries. These include, in particular, the "middle income trap" growing labor shortages and labor costs, and the issue of openness of domestic labor markets to foreign economic immigration. Many countries, after reaching approximately $60 \%(+/-10 \%)$ of American prosperity, cease to catch up with the United States - which, as the largest economy in the world, is the frame of reference. This occurred, among others, in Greece and Portugal and in some Latin American or Middle East countries which are based on low and medium advanced production. The "middle income trap" is caused by the declining return on investment, forcing the search for other sources of development - primarily switching to innovation and technically advanced capital (Aiyar et. al., 2013).

\section{Controversies around V4 cooperation}

What raises the biggest discussions among the many controversies in the Visegrad Group is political cooperation considered at three levels: relations among the V4 countries, relations between the V4 countries and the EU, and other external relations of the countries of the region, especially with the USA, with Russia and with Ukraine. The approaches presented in the international forum can be simply reduced to the rule of "four countries and three positions"; with Hungary and Poland showing a tendency to pursue separate policies, and the Czech Republic and Slovakia usually have similar perspectives. Relations within the V4 are slightly different in terms of political and economic issues, which for several years have been divided into the countries of "illiberal democracy" and countries continuing the modified version of the 1990s development strategies. Hungary (since 2010) and Poland (since 2015) have been moving away from the Western European separation of powers. Nationalist-populist and conservative groups rule there. They centralize the executive branch while implementing three policies: statist (based on large state corporations), economically liberal (in the sphere of economic regulations, the pension system) and paternalistic in the social sphere (lowering the retirement age, providing extensive family transfers, marginalizing social dialogue).

What is occurring in these countries is a shift towards state capitalism. In the conditions of weakness of domestic capital, an essential part of this return is to increase the role of the state in the economy, including the share in ownership of enterprises. These activities are primarily aimed at overcoming the risks associated with strengthening the dependent position of the market economy and reducing the threat of the "middle income trap." However, basing the development 
of the economy on the state sector is very controversial in the conditions of post-communist CEE countries $^{11}$. The experience of nomenclature statism shows that support for state champions of the economy is burdened by the growing risk of poor resource allocation. The mixing of ownership, regulatory and management functions favours new forms of monopolization and politicization of the economy and facilitates corruption, as well as lowers institutional standards in the public sphere. It is also associated with a lower efficiency of state-owned enterprises compared to companies with foreign capital and private domestic capital (IMF, 2019; Bałtowski and Kwiatkowski, 2018). The crises of state-owned banks in the Czech Republic in the 1990s (and later also in Slovenia) confirmed the negative consequences of similar actions. Despite the state support for reindustrialization, export promotion of domestic companies and modern technologies in Hungary and Poland, there is no evidence that these countries are now able to effectively deviate from the FDI driven growth strategy (Pula, 2018, pp. 208-212).

The view is being discussed, however, that it is more important for the future to eliminate of the performance gap between domestic labor productivity and leading world economies, to significantly strengthen the spill over effect in domestic enterprises and to increase their competitiveness, than to renationalize enterprises (Farkas, 2016, p. 209; Myant, 2018, p. 302). The Czech Republic and Slovakia have not significantly changed their development model. In the Czech Republic, where parties with stronger centre-left and liberal preferences rule, and in Slovakia, where the party of conservative Social Democrats and nationalists is in power, an ideologically homogeneous block of power has not formed. Anti-liberal political tendencies are weaker in these countries and have less impact on the economy. However, the situation of Slovakia is fundamentally different compared to all the V4 countries. It has belonged to the euro area since 2009. Thus, it participates in the "hard core" of integration processes, which has granted to it significant political benefits, including greater capacity for building coalitions and forcing own interests in the European Union. In contrast, Poland and the Czech Republic are distancing

\footnotetext{
${ }^{11}$ In Hungary, between 2010 and 2013, the value of the state share in ownership doubled (Farkas, 2016, p. 414). Between 2010 and 2016, over $80 \%$ of renationalization transactions concerned foreign entities (Mihalyi, 2016, p. 588). Poland has also increased state ownership, especially in the financial services and the energy sector (e.g. in banking, the share of national capital controlled by the state has exceeded $52 \%$, in the energy sector 60\%). For comparison, the share in the assets of the banking sector with dominant foreign capital in the Czech Republic and Slovakia is $92 \%$ and $84 \%$ respectively (in UK 38\%, in Italy $8 \%$, in Germany 7\%, in France and Spain 5\% each) (NBP, 2018, p. 88).
} 
themselves from adopting the single currency, which at this stage of development places them on the outskirts of the EU.

In addition to systemic and political divergences, there are also other types of differentiation among the V4 Group countries, including those resulting from a different definition of national interests. For example, Poland has the ambition to become a significant European gas hub, which conflicts with the similar aspirations of Hungary cooperating in this respect with the Russian Federation. These divergences have specific consequences, including the weak presence in the public debate of joint economic initiatives (analogous to the Swedish-Danish road and rail bridge connecting Malmo with Copenhagen), which would testify to the vitality and prospects of the Group's cooperation. Although some activities have recently been undertaken, Via Carpathia remains the only significant project, and the weakness of joint activities is illustrated by the financing of the Visegrad Fund which has a budget of around EUR 7-8 million per year. The main differences between the EU and governments of the V4 countries concern mainly the interpretation of the EU law in the areas of system and migration.

New political tensions create controversies in the assessment of the directions of systemic changes, of the observance of European values enshrined in the Treaty (such as separation of powers, rule of law, independence of judges, freedom of the media and minority rights), as well as the extent of further participation in the development of European integration. Hungary and Poland entered into an open conflict with the EU institutions and the procedure defined in Art. 7 of the EU treaty has been set out against the two states to counteract the threat to European values - for the first time in history the European Union (Bluhm and Varga 2019; Zielonka 2018). Slovakia and the Czech Republic are not introducing legal and institutional changes that would raise EU reservations comparable to those regarding Poland and Hungary. However, Slovakia, the Czech Republic and Hungary are accused of abusing the use of EU funds. The attitude towards the migration crisis has become an important test of the coherence of the V4 states in the EU. Hungary, the Czech Republic, Poland, and Slovakia acted as opponents of unrestricted access of migrants to the European Union and began to be treated as a "coalition of the reluctant" operating in opposition to the other Member States.

The matter was treated by the V4 as an element of the subregion's impact on the future of the EU. However, they fail to reach a common position on other prominent issues, such as the spectacular vote on Donald Tusk's second term as President of the European Council (March 
2017), work on the Services Directive (the Mobility Package), and recently the position on climate neutrality and low-carbon transformation (UN COP25 Climate Summit in Madrid in December 2019). There are also significant differences between the V4 countries in the spheres of external relations and security policy. Although all these countries are members of NATO, they represent different positions. While Poland indicates Russia as the main security threat, Hungary and Slovakia openly cooperate and develop contacts with Moscow. The Czech Republic is also sceptical about the threats defined by Warsaw. Poland, unlike Hungary, pursues also by far the most pro-American policy. Poland is effectively seeking the location on its territory of NATO military bases and the presence of US troops, which is not supported by the other Visegrad Group countries (Koziej, 2019) ${ }^{12}$. Major differences are also visible in the energy policy. Hungary bases its security in this area primarily on cooperation with the Russian Federation, treating the implementation of the joint project as an opportunity to restore the pragmatic cooperation between the East and the West (nuclear power plant in Paks, support for the South Stream). On the other hand, Poland emphasizes the need to weaken the energy dependence on Russia in favour of cooperation with Norway and Denmark (the Baltic Pipe gas pipeline) and with the USA (the LNG terminal) (Bokajło, 2019).

After joining the EU, the V4 countries consistently supported the EU principle of the opendoor policy, whose important manifestation became the Eastern Partnership (EP) Polish-Swedish initiative in 2009, assumed to be an instrument of active participation in shaping the EU neighbourhood policy towards Eastern and Southeast Europe. Currently, the EP is considered a rather moderate success, as evidenced by the complex EU political relations with Georgia, Moldova and Ukraine or the fiasco of the policy towards Armenia, Azerbaijan and Belarus ${ }^{13}$. The Ukrainian-Russian conflict has changed the context of Eastern policy of the countries of Central Europe, including the nature of cooperation with Ukraine. The Visegrad countries became divided in the attitudes towards the annexation of Crimea and the war in Donbas. Although all the countries

\footnotetext{
12 Opinion polls confirm that the countries of the Group differ in their approach to the United States and Russia. The highest level of trust in the USA is in Poland (50\%), the lowest in Slovakia (27\%). The Polish public opinion feels the highest level of distrust towards Russia, while the Slovaks - on the contrary - feel the lowest level of distrust towards Russia (Gyárfášová and Mesežnikov, 2016, p. 6).

${ }^{13}$ See. "New Eastern Europe" No. 3-4/2019 a special issue with the statements of politicians who initiated the Eastern Partnership (C. Bild, R. Sikorski), as well as well-known experts (e.g. A. Aslund).
} 
in the region support EU sanctions against the Russian Federation, relations with Ukraine (except for Poland) remain secondary to relations with Russia.

Relations with China are quite a new aspect of cooperation between the V4 countries (since 2016 all the Visegrad countries have been operating as part of a strategic partnership with the PRC). The key role of these countries in the Chinese strategy towards Central Europe in the case of Poland results from its geostrategic location, for Hungary it stems from its political attitude and for the Czech Republic it is the result of its increasing technological advancement. However, the tensions in the Chinese American relations and the recognition by NATO of China as a country that could threaten the global security raise questions about the prospects for the V4 cooperation with Beijing.

\section{Conclusions}

The V4 is mainly a forum for political cooperation of relatively low economic importance (the Visegrad countries generate about $6 \%$ of the total EU GDP). They are just beginning to implement joint major projects. The revival of the Group is political and is mainly associated with the migration crisis and the opposition to the centralist and federalist concept of UE integration. In the context of the limited complementarity of economies, the diversity of national trajectories for political and economic development in the V4 countries usually characterized by neorealist or functionalist theories of European integration. A different perspective of capitalism with the leading role of foreign investors draws attention to the position in the international division of labor, which is both a premise and an effect of the peripheral status of the V4 states compared to the core countries of the EU, especially Germany. This status is one of the main causes of the Group's weakness, which is also aggravated by the diverse political goals of the V4 countries, their low level of economic integration and the key role of foreign capital in the Visegrad economies. This reduces the position of Central Europe in international value chains and reduces the possibility of economic policy being coordinated by governments in the countries of the region.

Other aspects of the Visegrad Group status in the EU are also relevant. Their growing importance among Germany's most important economic partners strengthens their negotiating power. The V4 countries have become an important source of improving the international competitiveness of the largest economy in the EU. The V4 can therefore defend the interests of other CEE countries, especially in the debate on a "Europe of many speeds." It weakens some 
divisions; hence its importance may grow, due to the gradual development of common positions regarding energy security problems, migration threats and the future of the common market. The V4 has an opportunity to become a regional policy tool, affecting the reorientation communication and energy routes from East-West to North-South, which would foster greater EU cohesion.

However, different perceptions of threats and various strategic interests (e.g. those of Poland and of Hungary) may constitute a real obstacle in this respect. The policy of the V4 countries regarding the divisions in the $\mathrm{EU}$ is often inconsistent. On the one hand, they are closer to the countries of Western and Northern Europe, which have trade surpluses and balanced budgets. On the other hand, like the South of Europe, the V4 economies belongs to the not very innovative peripheries of the EU (see European innovation scoreboard country ranking, in which only the Czech Republic is included in the "strong innovators" category). The V4 are divided by their attitudes towards the euro area. Slovakia is a member of Euroland; Hungary pragmatically does not reject the possibility of joining; however, Poland and the Czech Republic do not currently see such a need.

Another dividing line runs around the climate neutrality and low-carbon transformation, where a lonely, fossil fuel dependent Poland does not find support from the other V4 members on the EU forum, which may limit its access to funds under the Just Transformation Mechanism. In the dispute regarding the admission of migrants from North Africa and from the Middle East, the Group's position is consistent with the approach of many other EU countries questioning the relocation rules promoted by the EC. The consistent demand for the EU external borders to be sealed has received support, an example of which is the strengthening of Frontex. The Visegrad Group is divided in the discussion on the system of European values and the rule of law. Hungary and Poland are weakening their political position due to controversies regarding political issues. This involves the possibility of introducing a mechanism for making the payment of EU funds conditional on the application of the rule of law. Czechs and Slovaks are not faced with similar charges, which is important for their participation in discussions on reforms and on the future of the European Union. As a result, the role of the Visegrad Group in the EU is determined more by the resultant interests of individual countries than by their cooperation within the Group. 


\section{References}

1. Aslund, A. (2008), How Capitalism was Built. Transformation of Central and Eastern Europe, Russia and Central Asia. Cambridge University Press, New York.

2. Aykut, D., Sanghi, A. and Kosmidou, G. (2017), What to Do When Foreign Direct Investment is Not Direct or Foreign: FDI Round Tripping. World Bank Policy Research Working Paper No. 8046, April 28.

3. Bałtowski M., Kwiatkowski G. (2018) Przedsiębiorstwa państwowe we współczesnej gospodarce. PWN, Warszawa.

4. Bluhm, K., Varga, M. (2019) New Conservatives in Russia and East Central Europe. London, New York: Routledge.

5. Bohle D., Greskovits B. (2012) Capitalist Diversity on Europe's Periphery. Cornell University Press, Ithaca .

6. Bokajło J. (2019) Dependence on Hydrocarbons as a factor Destabilizing the Economic Order of the European Union with Particular Emphasis on the Role of the Visegrad Group Countries, in: J.M. Fiszer, A. Chojan, P. Olszewski (eds), Place and Role of the Visegrad Group Countries in the European Union, ISP PAN, Warsaw, pp. 189-213.

7. Chojan A. (2019) The Visegrad Group and the Migration Crisis in Europe: A Discussion in the Context of the Global Strategy for the European Union's Foreign and Security Policy, in: J.M. Fiszer, A. Chojan, P. Olszewski (eds), Place and Role of the Visegrad Group Countries in the European Union, ISP PAN, Warsaw, pp. 87-102.

8. Deloitte (2014) CE Top 500 CE TOP 500. Rzeczpospolita, 3.09.

9. Farkas B. (2016) Models of Capitalism in the European Union. Post-crisis Perspectives. Palgrave, London.

10. Góralczyk B. (2018) New Division Lines in the European Union: How to Cope with Them? Studies in European Affairs, No 4, pp. 9-21.

11. Gorzelak G., Goh Ch. Ch. (eds.) (2010) Financial Crisis in Central and Eastern Europe: From Similarity to Diversity. Scholar, Warsaw.

12. IMF (2019) Reassessing the Role of State-Owned Enterprises in Central, Eastern, and Southeast Europe, file://C:/Users/Inspiron/Downloads/RRSOECESEEEA.pdf (access 31.01.2020).

13. Jasiecki K. (2013) Kapitalizm po polsku. Między modernizacja a perypetiami Unii Europejskiej. IFiS PAN, Warszawa. 
14. Jasiecki K. (2019) A Reconfiguration of the Interest Representation System in the European Union. Polish Sociological Review. No 2, pp. 123-140.

15. Judt, T. (2005) Postwar : A History of Europe Since 1945. Penguin Press.

16. Judt, T. (1996). A Grand Illusion?: An Essay on Europe. Douglas \& McIntyre.

17. Koziej S. (2019) The Role of the Visegrad Group in Eastern Security, in: J.M. Fiszer, A. Chojan, P. Olszewski (eds), Place and Role of the Visegrad Group Countries in the European Union. ISP PAN, Warsaw, pp 69-86.

18. Kubisz J. (2008) Słowacja dba o własny interes. Rzeczpospolita, 19 grudnia.

19. Kużelewska E., Bartnicki A.R. (2017) Grupa Wyszehradzka - nowe wyzwania bezpieczeństwa i perspektywy współpracy. Rocznik Integracji Europejskiej, No 11, pp. 103-117.

20. Malova D. (2017) Transformation Experiences in Slovakia, Friedrich Ebert Stiftung, Berlin.

21. McDonagh K. (2014) A view on Central Europe: Does the V4 have a future? Bratislava - Globes, July 16.

22. Mihalyi P. (2016) Renacjonalizacja i recentralizacja w gospodarce Weegier, 2010-2016. Economic Studies, No 4, pp. 579-597.

23. Muresan L., Georgescu A. (2017) A Romanian Perspective on the Three Seas Initiative. The Market for Ideas, No7-8.

24. Myant M., Drahokoupil J. (2011) Transition Economies: Political Economy in Russia, Eastern Europe and Central Asia. Wiley \& Sons. Hoboken.

25. Myant M. (2018) The Limits to Dependent Growth in East-Central Europe, Revue de la regulation, Autum, https://journals.openedition.org/regulation/13351?lang=en (access 12.12.2019).

26. New Eastern Europe (2019) No. 3-4.

27. Nölke A., Vliegenhart A. (2009) Enlarging The Varieties of Capitalism: The Emergence of Dependent Market Economies in East Central Europe. World Politics, No 61 (4).

28. Orłowski W. M. (ed.) (2018) Jak żyć z Euro? Doświadczenia krajów Europy Środkowo-Wschodniej, Polska Fundacja im. Roberta Schumana, Warszawa.

29. Orzelska-Stączek A. (2019) Should the Visegrad Group Become an International Organization Given the Challenges in International Relations? in: J.M. Fiszer, A. Chojan, P. Olszewski (eds), Place and Role of the Visegrad Group Countries in the European Union, ISP PAN, Warsaw, pp 117-134. 
30. Petrovici N. (2015) Dependenţă și dezvoltare. Economia politică a capitalismului românesc (Dependency and Development. The Political Economy of Romanian Capitalism) by Cornel Ban. Cluj-Napoca: Tact Publishing House, 2014, 293 pages. Studia Ubb Sociologica, 60 (LX), 2, 2015, pp. 137-151.

31. Popławski K. (2016) The role of Central Europe in the German economy. The political consequences. OSW, Warsaw.

32. Pula B. (2018) Globalization Under and After Socialism. The Evolution of Transnational Capital in Central and Eastern Europe. Stanford University Press.

33. Roszkowski W. (2015) East Central Europe, A Concise History. Warsaw, ISP PAN.

34. Rothschild Joseph. 1998. East Central Europe between the Two World Wars, University of Washington Press, Seattle and London.

35. Septimiu S. (2019) FDI in the Czech Republic: A Visegrád Comparison, Economic Brief 042, EC, February, https://ec.europa.eu/info/publications/foreign-direct-investment-czechrepublic-visegrad-comparison_en (access 10.09.2019).

36. Sikulova, K. Frank (2013) The Slovak experience with transition to market economy, Institute of Economic Research SAS, Bratislava.

37. Świder, K. (2018) Europa Środkowa jako obszar projektowania geopolitycznego. Studia Europejskie, No. 2, pp. 11-32.

38. The Economist (2019) Pocket World in Figures. London 2019.

39. Zbińkowski G. (2019) The Three Seas Initiative and its Economic and Geopolitical Effect on the European Union and Central and Eastern Europe. Comparative Economic Research. Central and Eastern Europe, No 2, pp. 105- 119.

40. Zielonka, J. 2018. Counter-Revolution. Liberal Europe in Retreat. Oxford, Oxford University Press. 